\title{
The effect of Quercus douglasii removal on understory yield and composition
}

\author{
J.W. BARTOLOME, B.H. ALLEN-DIAZ, AND W.D. TIETJE
}

Authors are professor, associate professor, and specialist, Department of Environmental Science, Policy, and Management, University of California, Berkeley 94720.

\begin{abstract}
The canopy of Quercus douglasii H. \& A. (blue oak) has been variously reported to enhance or suppress understory production. The effects of canopy removal have been reported only for the northern portion of blue oak's range. We removed all blue oaks from 6 plots in the central coast of California and found no significant change in understory biomass over 3 years. Understory herb cover averaged $32.6 \%$ on cleared plots, compared to $24.3 \%$ on uncut plots, but composition changed little with the exception of an increase in Erodium cicutarium (L.) L'Her. Clearing did not produce the distinctive species composition and forage enhancement under $\boldsymbol{Q}$. douglasii canopy reported in other studies, all based on comparisons between unmanipulated canopy and adjacent grassland. Our results suggest that the canopy effect could instead be caused by differences in sites occupied by trees. Clearing of $Q$. douglasii in regions with $50 \mathrm{~cm}$ or less of mean annual precipitation is not recommended for increasing forage production.
\end{abstract}

Key Words: oak savanna, canopy effect, forage

Oak-dominated hardwood rangelands occupy about 4 million hectares in California (Ewing et al. 1988). The Quercus douglasii H. \& A. (blue oak) series is the most widespread extending northward in the Sacramento Valley foothills and south through the San Joaquin Valley and central Coast Ranges (Allen et al. 1991). The canopy in the $Q$. douglasii savanna controls important ecosystem processes. Trees modify the understory environment (Jackson et al. 1990, Callaway 1990) and contribute structural diversity which enhances wildlife habitat (Block and Morrison 1987). The annual plants dominating the savanna understory grow at different rates (Frost and McDougald 1989) and differ in composition (McClaran and Bartolome 1989) when compared to treeless grassland. In regions with more than $50 \mathrm{~cm}$ mean annual precipitation, $Q$. douglasii canopy cover reduces understory forage yield compared to open grassland but may increase yields in drier regions ( $\mathrm{McCla}$ ran and Bartolome 1989).

Previous studies have reported forage increases following Quercus douglasii removal in the more mesic northern range of the species in the foothills around the Sacramento Valley (Kay 1987). One 19-year long study found that, although production increased after tree removal, forage produced on cleared areas was less than on natural grasslands (Heady and Pitt 1979). This result suggests a difference in site potential for natural grasslands and woodlands.

Range managers have recommended Quercus douglasii clearing for range management improvement, based on 2 studies in the northern part of the species' range showing increased forage yields after canopy removal (Heady and Pitt 1979, Kay 1987). However,

\footnotetext{
The authors wish to thank Hy Blythe, Richard Standiford, Lynn Huntsinger, and personnel from the California Youth Authority, Paso Robles, Calif., for their contributions to this study.

Manuscript accepted 20 Oct. 1993.
}

large-scale clearings for range improvement are no longer likely to be recommended (Standiford and Howitt 1991) because forage yields and utilization are often higher under individual trees in drier areas (Holland 1980), accelerated erosion with clearing (Pitt et al. 1978), and potential loss of wildlife habitat (Verner 1987). Small clearings in $Q$. douglasii stands are still recommended to increase habitat diversity for wildlife and allow wood harvesting.

Studies in the drier, more southern Quercus douglasii areas in the central Coast Ranges and San Joaquin Valley Foothills, showing different species composition and greater production under the canopy all compared canopy to nearby openings, not the effects of canopy removal (Holland 1980, Frost and McDougald 1989, McClaran and Bartolome 1989). Studies comparing open and canopy all confound site and canopy effects. Quercus douglasii may simply occur on more productive sites within the savanna mosaic.

We report understory forage response to Quercus douglasii removal on a site within the drier part of its range.

\section{Study Area}

The 80-ha study site is located approximately $16-\mathrm{km}$ west of Paso Robles, Calif. (Lat. $35^{\circ} 40^{\prime} \mathrm{N}$, Long. $120^{\circ} 37^{\prime} \mathrm{W}$ ), in the Central Coast Range. The site falls within the southern region of the Quercus douglasii series (Allen et al. 1991) at 520-m elevation. The vegetation belongs to the blue oak/grass subseries, and is dominated by $Q$. douglasii with an understory of annual herbs. The soil has been classified as Dibble clay loam, a Typic Argixeroll derived from a weathered shale parent material (Lindsey 1983). Annual precipitation averaged $36 \mathrm{~cm}$ over 100 years at the nearest weather station, Paso Robles (NOAA 1991), but is about $50 \mathrm{~cm}$ on the research site. Monthly rainfall during the study was below average the first 2 years, but reached average in the third year because of an exceptionally wet March 1991 (Fig. 1). The study site is moderately grazed, winter through spring, by 20 cow-calf pairs.

\section{Methods}

In fall 1987, 6 pairs of circular 0.04 -ha plots were located in Quercus douglasii stands. Canopy cover was measured with a spherical densiometer. DBH and height of all trees over $10-\mathrm{cm}$ DBH and fuelwood volume was measured on the plots (Standiford et al. 1990). In summer 1988, a randomly selected plot from each pair was cleared of all trees. In fall of 1988 , a $1.0-\mathrm{m}^{2}$ cage was randomly placed in each of the 12 plots. Botanical composition and forage production were measured each spring at the end of the growing season beginning in 1989 and continuing for 3 growing seasons. Each spring, botanical composition and cover were measured with a 10 -point frame, 100 points per plot inside each cage. Then ungrazed forage was measured by clipping square $1 / 16 \mathrm{~m}^{2}$ plots inside the cage to estimate forage productivity. 


\section{Cumulative Precipitation, Paso Robles}

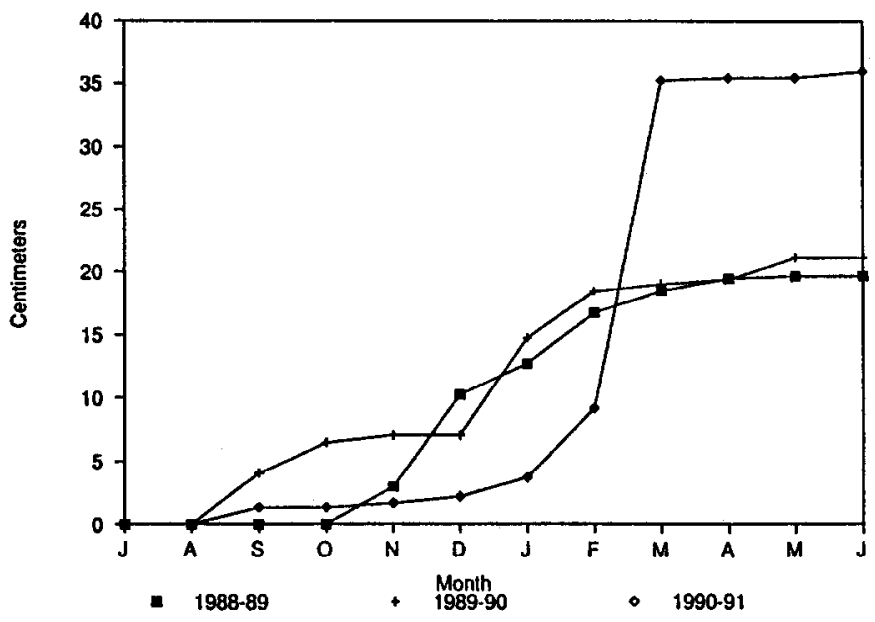

Fig. 1. Monthly precipitation at Paso Robles, Calif., for the 1988-89, 1989-90, and 1990-91 seasons. Total rainfall averaged $36 \mathrm{~cm}$ over 100 years record (NOAA 1991). Precipitation at the study site is approximately $\mathbf{4 0} \%$ greater.

The data were analyzed with ANOVA using a randomized complete block (plot pairs) split in time. The plot pairs (cut and uncut) are blocks, with tree removal (cutting) the main treatment. Years are analyzed as the split treatment. Dependent variables are ungrazed forage, total herb cover, number of herb species per plot, and understory botanical composition. Taxa hit during point sampling totaled 51 . The 18 taxa which occurred in more than 1 sample were each subjected to ANOVA. The 0.1 level of significance was chosen for factors analyzed.

\section{Results}

The study plots averaged $68 \%$ canopy cover. Fuelwood volume averaged $2.55 \mathrm{~m}^{3} /$ plot, for an estimated yield of about 1 cord $/ \mathrm{plot}$. Trees per ha averaged 500, and basal area averaged $11.48 \mathrm{~m}^{2}$ per ha. None of these variables differed significantly among plots, and values are characteristic of the blue oak/grass subseries (Allen et al. 1991).

Forage production differed significantly only among years (Table 1). Tree removal had no significant effect on forage production, which averaged $36.64 \mathrm{~g} / \mathrm{m}^{2}$ in $1989,60.16 \mathrm{~g} / \mathrm{m}^{2}$ in 1990 , and $58.08 \mathrm{~g} / \mathrm{m}^{2}$ in 1991 (Fig. 2).

Herbaceous cover significantly increased after tree removal, measuring $24.3 \%$ uncut and $32.6 \%$ in openings. No recruitment of Quercus douglasii was observed during the study on any plots.

Tree removal caused significant decreases in cover of $\mathbf{2}$ grasses (Fig. 3). No other taxa were significantly affected by tree cutting alone.

Cover of a number of species changed among years, but was unaffected by tree removal (Fig. 4). Bromus mollis L., the most common grass in the study area, declined significantly from $9.1 \%$ cover in 1989 to $2.6 \%$ cover in 1991 . Viola sp. increased significantly from $0.7 \%$ in 1989 to 4.0 and $4.5 \%$ in 1990 and 1991 , respectively. Species of Sanicula became significantly more abundant in 1990 and 1991. Cerastium spp. were not recorded after 1989 , a significant decline.

Several taxa showed significant interactions of tree removal and year. Erodium cicutarium cover did not change on uncut plots, but increased significantly on the cut plots by 1991 (Fig. 5). Stipa pulchra Hitch. was present on cut plots at the low cover of $0.8 \%$ in 1990 , absent other years, but present at $0.2 \%$ on uncut plots in 1991
Table 1. F-ratios ( $F_{n, m}$ where $n$ and $m$ are degrees of freedom) from analysis of variance using a split-plot design. Significant $F$-ratios are marked with asterisks, $p<0.01=* * * 0.01<p<0.05=* * 0.05,<p<0.10$ $=$ *.

\begin{tabular}{lccc}
\hline \hline & \multicolumn{3}{c}{ Factor } \\
\cline { 2 - 4 } & $\begin{array}{c}\text { Tree } \\
\text { Removal }\end{array}$ & $\begin{array}{c}\text { Year } \\
\left(\mathrm{F}_{2,20)}\right.\end{array}$ & $\begin{array}{c}\text { Year } \times \text { Tree } \\
\text { Removal } \\
\left(\mathrm{F}_{2,20}\right)\end{array}$ \\
\hline Variable & $\left(\mathrm{F}_{1,5}\right)$ & 0.659 & 1.030 \\
\hline Avena barbata & $5.084^{* * *}$ & $14.316^{* * *}$ & 0.356 \\
Bromus mollis & 0.934 & 1.150 & $2.687^{*}$ \\
Brodiaea spp. & 0.298 & 0.513 & 0.074 \\
Bromus diandrus & 2.360 & 1.116 & 0.371 \\
Carduus pycnocephalus & 0.861 & 0.025 & 1.675 \\
Centaurea melitensis & 0.014 & $2.776^{*}$ & 2.138 \\
Cerastium spp. & 2.002 & 1.631 & 0.052 \\
Daucus pusillus & 1.359 & $3.908^{* *}$ & $3.669^{* *}$ \\
Erodium cicutarium & $9.625^{* * *}$ & 0.331 & 1.167 \\
Hordeum hystrix & $4.839^{* * *}$ & 0.404 & 1.149 \\
Hypochoeris glabra & 0.307 & 0.855 & 0.196 \\
Medicago polymorpha & 3.745 & 1.092 & 0.157 \\
Poa scabrella & 1.818 & $3.397^{*}$ & 1.264 \\
Sanicula bipinnata & 3.449 & $3.114^{*}$ & 0.179 \\
Sanicula bipinnatifida & 0.268 & 1.505 & 0.306 \\
Stellaria media & 0.419 & 1.809 & $2.672^{*}$ \\
Stipa pulchra & 2.494 & $2.856^{*}$ & 1.321 \\
Viola sp. & 2.659 & 0.552 & 2.554 \\
Number of taxa & 0.101 & $2.62^{*}$ & 2.25 \\
Ungrazed biomass & 0.025 & 1.42 & 1.31 \\
Cover & $4.65^{*}$ & & \\
\hline
\end{tabular}

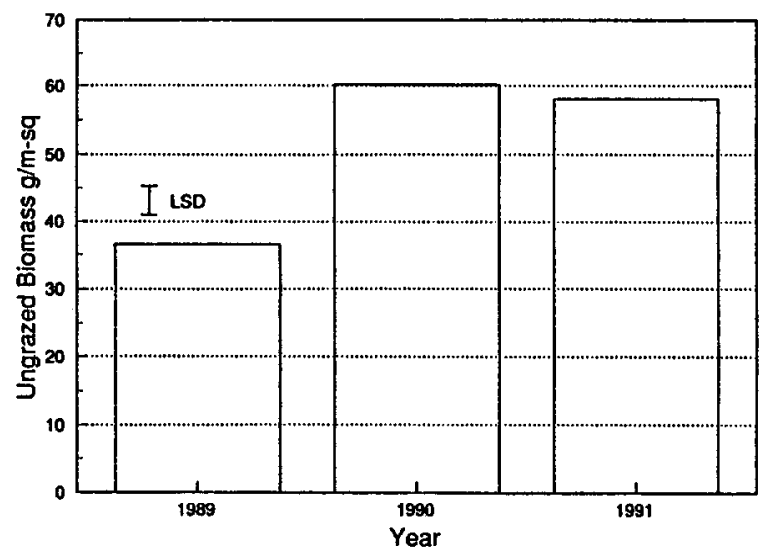

Fig. 2. Ungrazed biomass in spring. LSD $(p<0.1)=4.907$.

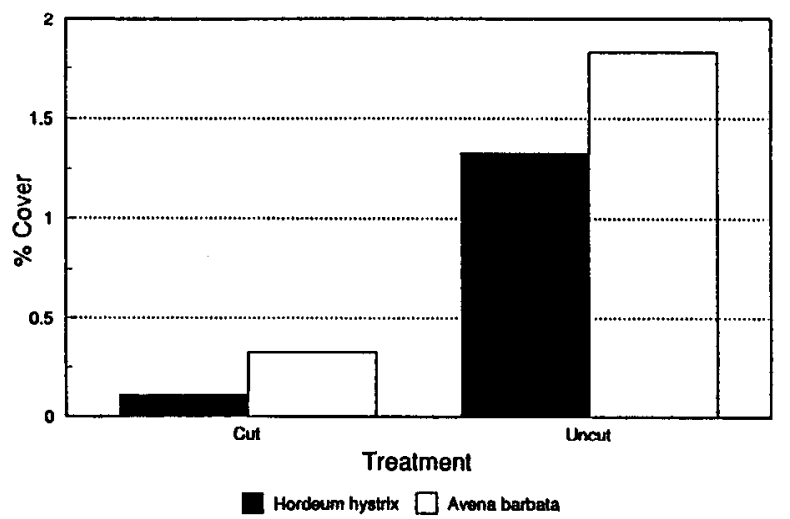

Fig. 3. Percent cover of 2 grass species affected by tree removal (cutting). Differences between treatment (cut vs. uncut) from ANOVA are significant at $p<0.01$. 


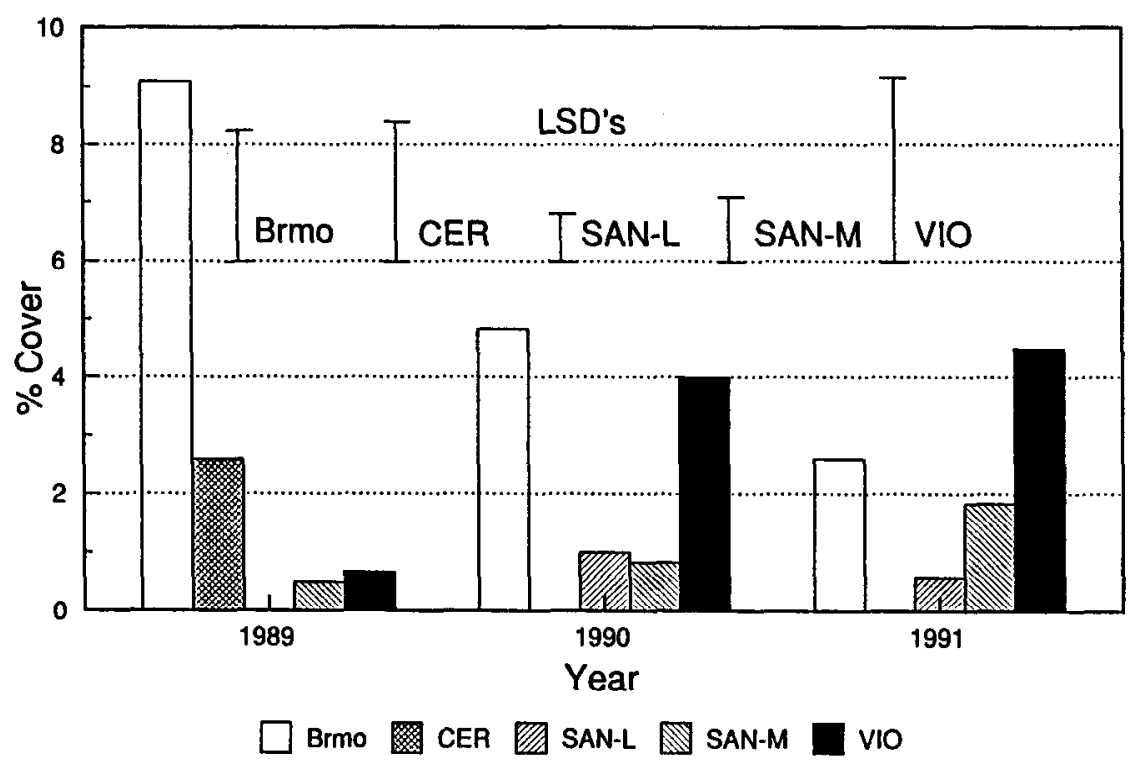

Fig. 4. Percent cover for taxa affected by year. Species names, codes, and LSD's $(p<0.1)$ are Brmo $=$ Bromus mollis (LSD $=2.13)$, CER $=$ Cerastium spp. $($ LSD $=2.17)$, SAN-L (LSD = 0.68) and SAN-M (LSD = 0.96) are 2 species of Sanicula, V10 = Viola sp. $($ LSD $=3.00)$.

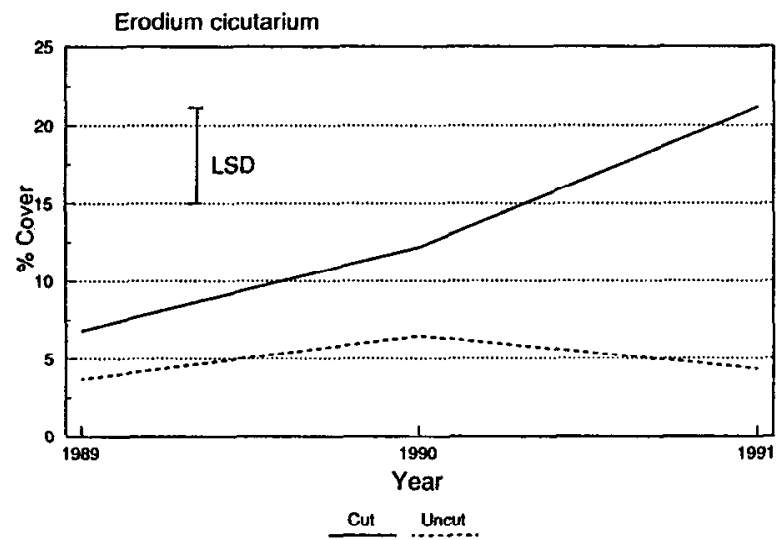

Fig. 5. Percent cover of Erodium cicutarium as affected by the interaction of tree removal (cutting) and year. LSD $(p<0.1)=7.92$.
(Fig. 6). Brodiaea spp. occurred at very low cover in the cut samples in 1989 and in uncut samples in 1991 (Fig. 6).

\section{Discussion and Conclusions}

Removal of Quercus douglasii overstory did not affect understory forage production on the relatively xeric study site. Changes in species composition due to treatment were also relatively minor, with the exception of increase in Erodium cicutarium on cut plots in the third year. The small, but statistically significant, changes observed in cover of perennial species of Sanicula, Brodiaea, and Stipa were likely due more to sampling variability than tree removal. In contrast to the results of McClaran and Bartolome's (1989) survey comparing open and understory composition, which showed distinctive canopy and open communities, removal of $Q$. douglasii neither affected composition nor the number and diversity of understory species. The effects of year on understory biomass and composition were more important than canopy removal.

Dry weather patterns during the study may have reduced the response of understory species to tree removal. However, dry years

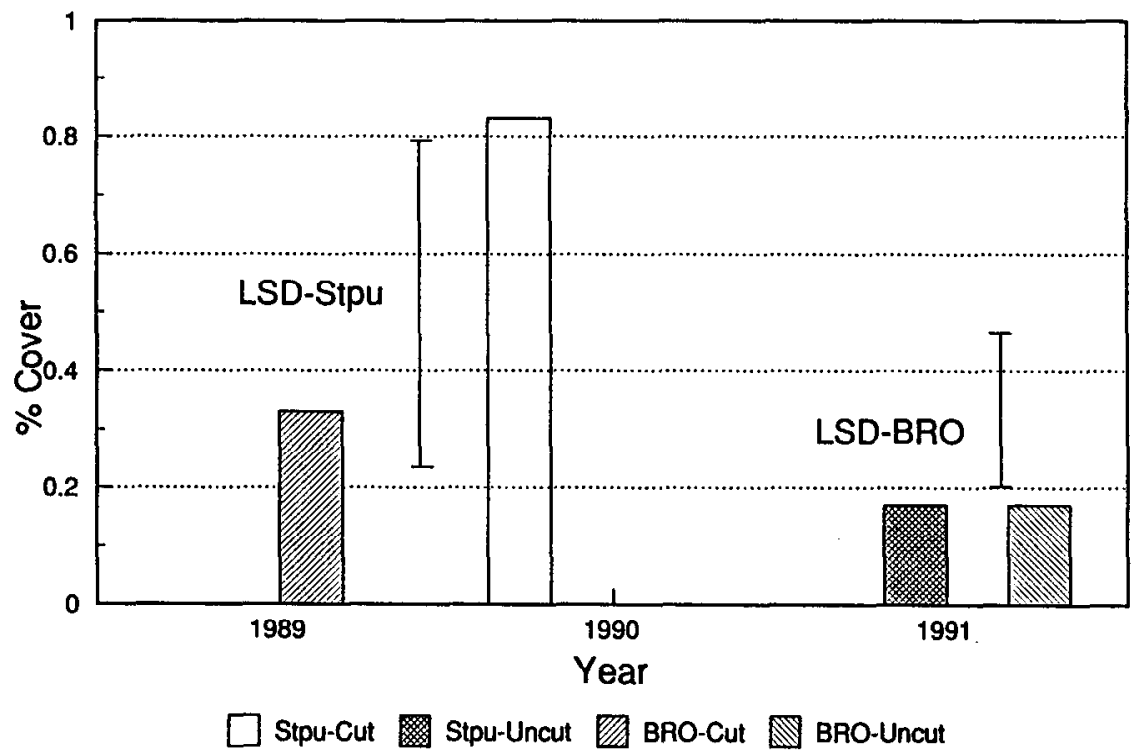

Fig. 6. Percent cover of Stipa pulchra (Stpu) and Broadiaea spp. (BRO) as affected by the interaction of tree removal (cutting) and year. LSD's ( $p<0.1)$ for Stpu $=0.684$, BRO $=0.324$. 
are common and so should be the lack of understory response. Tree removal may open up wildlife habitat and offer the opportunity to sell wood, but did not produce benefits for livestock production under conditions of this study. Removal of Quercus douglasii for forage production was not justifiable based on our results.

Our results are consistent with the hypothesis that Quercus douglasii occupies different sites than the adjacent open grassland. The studies showing canopy enhancement in the southern part of the $Q$. douglasii savanna (Callaway 1990, Frost and McDougald 1989, Holland 1980, McClaran and Bartolome 1989) all confound site and canopy effects because overstory canopy cover was not manipulated experimentally. Significant differences in community composition between openings and canopy like those found by McClaran and Bartolome (1989) did not appear after $Q$. douglasii removal on our plots. Presumed canopy effects on composition and production, which are so far based only on results comparing naturally occurring patterns of trees, may instead be mainly a site effect. If trees do occur on different microsites, then this result also has important implications for understanding and managing regeneration.

\section{Literature Cited}

Allen, B.H., B.A. Holzman, and R.R. Evett. 1991. A classification system for California's hardwood rangelands. Hilgardia 59:1-45.

Block, W.M., and M.L. Morrison. 1987. Conceptual framework and ecological considerations for the study of birds in oak woodlands, $p$. 163-173. In:T.R. Plumb and N.H. Pillsbury (tech. coords.) Multiple use management of California's hardwood resources. USDA Forest Serv. Gen. Tech. Rep. PSW-100.

Callaway, R.M. 1990. Effects of Quercus douglasii on grassland productivity and nutrient cycling in central California. Ph.D. Diss. Univ. Calif., Santa Barbara.

Ewing, R.A., R.N. Tuazon, N. Tosta, L. Huntsinger, R. Marose, K. Nielson, R. Motroni, and S. Turan. 1988. California's forests and rangelands: growing conflict over changing uses. Forest and rangeland resources planning, California Dep. Forest. and Fire Protection, Sacto.
Frost, W.E., and N.K. McDougald. 1989. Tree canopy effects on herbaceous production of annual rangeland during drought. J. Range Manage. 42:281-283.

Heady, H.F., and M.D. Pitt. 1979. Reactions of a northern California grass-woodland to vegetational conversions. Hilgardia 47:51-73.

Holland, V.L. 1980. Effect of blue oak on rangeland forage production in central California, p. 314-318. In: T.R. Plumb (tech. coord.) Ecology, management and utilization of California oaks. USDA Forest Serv. Gen. Tech. Rep. PSW-44.

Jackson, L.E., R.B. Strauss, M.K. Firestone, and J.W. Bartolome. 1990. Influence of tree canopies on grassland productivity and nitrogen dynamics in a deciduous oak savanna. Agr. Ecosys. and Environ. 32:89-105.

Kay, B.L. 1987. Long-term effect of blue oak removal on forage production, forage quality, soil, and oak regeneration, p. 351-357. In: T.R. Plumb and N.H. Pillsbury (tech. coords.) Multiple use management of California's hardwood resources. USDA Forest Serv. Gen. Tech. Rep. PSW-100.

Lindsey, W.C. 1983. Soil survey of San Luis Obispo County, California: Paso Robles Area. USDA Soil Conserv. Serv.

McClaran, M.P., and J.W. Bartolome. 1989. Effects of Quercus douglasii (Fagaceae) on herbaceous understory along a rainfall gradient. Madroño 36:141-153.

National Oceanic and Atmospheric Administration. 1991. Climatological data: California. Nat. Oceanic and Atmospheric Admin., Nat. Climatic Data Center, Asheville, N.C.

Pitt, M.D., R.H. Burgy, and H.F. Heady. 1978. Influence of brush conversion and weather patterns on runoff from a northern California watershed. J. Range Manage. 31:23-27.

Standiford, R.B., and R.E. Howitt. 1991. A dynamic model of California's hardwood rangelands, p. 279-285. In: Standiford, R.B. (tech. coord.) Proc. Symp. on Oak Woodlands and Hardwood Rangeland Management. USDA Forest Serv. Gen. Tech. Rep. PSW-126.

Standiford, R.B., W.D. Tietje, and J.W. LeBlanc. 1990. Harvesting firewood for sustained yield on oak rangelands. Univ. California Coop. Ext. Pub. 21487.

Verner, J. 1987. The importance of wildlife habitats for wildlife in California, p. 162-173. In: T.R. Plumb and N.H. Pillsbury (tech. coords.) Multiple use management of California's hardwood resources. USDA Forest Serv. Gen. Tech. Rep. PSW-100. 